\title{
As interartes e seu lugar no contexto atual disciplinar dos cursos de graduação e pós-graduação em arte nas universidades brasileiras.
}

\author{
EDUARDO RAMOS
}

Eduardo Ramos é graduado em artes visuais pela Universidade Federal de Uberlândia. Atualmente é mestrando do larte/UFU no departamento de música e tem como pesquisa o processo interartístico sonoro/visual nas obras pictóricas e musicais do artista Dorival Caymmi. Professor de arte na educação básica da rede pública de ensino da Prefeitura Municipal de Uberlândia e da Secretaria de Educação do Estado de Minas Gerais. Artista visual e músico instrumentista (contrabaixo e violão).

Afiliação: Universidade Federal de Uberlândia

Lattes: http://lattes.cnpq.br/3272664661790760

Orcid: https://orcid.org/0000-0003-4369-3735 


\section{- RESUMO}

Este artigo apresenta um panorama sobre a importância das interartes e a abordagem dessa disciplina dentro dos institutos de Artes das universidades brasileiras. Para demonstrar essa importância, apresento estudos sobre a interação da música e das artes visuais. A primeira parte do artigo traz um histórico epistemológico das correspondências artísticas e como esse conhecimento tem sido abordado nesses cursos, observando as construções curriculares dos cursos de graduação e pós-graduação e suas ofertas de disciplinas na construção do conhecimento e da produção artística através das interartes. Num segundo momento, busco uma análise das disciplinas curriculares dos institutos de Artes que versam sobre o assunto, apresentando atravessamentos e encontros das linguagens artísticas. Tomo para análise a relação interartística da música e da pintura num panorama histórico e contemporâneo. Ao final, busco mostrar que os diálogos interartísticos possuem grande relevância na formação do docente do ensino básico, que, por exigência das bases curriculares, necessita compreender e articular as várias linguagens no processo de arte-educação nas escolas de ensino básico. Tal compreensão do processo criativo interartístico é exigida na docência, seja teórica ou de produção artística em sala de aula.

\section{PALAVRAS-CHAVE:}

Interartes. Correspondências das artes. Arte-educação.

\section{- ABSTRACT}

This article presents an overview of the importance of Interarts and the approach to this discipline within the arts institutes of Brazilian universities. To demonstrate this importance, I present studies on the interaction of music and the visual arts. The first part brings an epistemological history of artistic correspondence and how this knowledge has been approached in these undergraduate courses. Observing the curricular constructions of undergraduate and graduate courses and their offer of disciplines in the construction of knowledge and artistic production through Interarts. In a second moment, I seek an analysis of the curricular subjects of the arts institutes that deal with the subject, presenting crossings and encounters of artistic languages. I take for analysis the inter-artistic relationship of music and painting in a historical and contemporary panorama. In the end, I seek to show that inter-artistic dialogues have great relevance in the training of basic education teachers, who, as required by the curricular bases, need to understand and articulate the various languages in the art/education process in basic education schools. Understanding the interartistic creative process required in teaching, whether theoretical or artistic production in the classroom.

\section{- KEYWORDS:}

Interarts. Correspondence of the arts. Art education. 


\section{Introdução}

Os cursos de graduação em Artes no Brasil, dentro das universidades públicas e privadas, não têm se preocupado com uma matéria muito importante no contexto contemporâneo, que é a disciplina de interartes. Para o professor de educação básica, essa ausência na sua formação dificulta a transmissão de conhecimentos interartísticos aos seus alunos. Pouco oferecida nos cursos de graduação em Artes, essa disciplina tem gerado interesse em institutos de graduação em Filosofia e Linguística. Nas artes, são os cursos de pós-graduação que se interessam mais sobre esse assunto, assumindo pesquisas amplas e diversificadas. Esse tema traz à tona questões do processo interartístico tão importantes para artistas, pesquisadores de arte e professores, principalmente quando falamos de arte contemporânea, que, no seu processo de criação, tem com as interartes uma relação extremamente relevante.

Nos cursos de graduação, o caráter formativo de uma linguagem artística específica é um itinerário bem definido, o que dificulta a inserção do pensamento contemporâneo das interartes, pelo qual a interação e a pluralidade das linguagens artísticas são premissas de criação. O pesquisador Etienne Souriau, no prefácio de seu livro A correspondência das artes (SOURIAU, 1947, p. 3), parafraseia o poeta Victor Hugo quando este dizia que os ventos são todos os ventos. Para Souriau, as artes são todas as artes, e exemplifica dizendo que, numa sinfonia, sons, ritmos, dissonâncias, cores e formas se apresentam e se misturam (SOURIAU, 1947, p. 3).

A lista de artistas do período modernista que atribuem características de diversas linguagens em suas obras é tão extensa quanto as metáforas usadas para designar tais influências. Wassily Wassilyevich Kandinsky (1866-1944) foi um dos autores que trouxeram a teoria da inseparabilidade entre tempo e espaço na arte. Tendo para outros teóricos da arte que o tempo é uma grandeza da música e o espaço uma grandeza das artes visuais, poderia então Kandinsky estar afirmando que a teoria de inseparabilidade seria, em tese, um processo interartístico entre música e pintura? Paul Klee (1879-1940) produziu obras com diálogos explícitos entre música e pintura. Sua formação como músico violinista trouxe vigor interartístico para sua obra pictórica. Para o escritor Hajo Duchting, "dificilmente existe um pintor e desenhista do século XX que lidou tão intensamente com a música como Paul Klee, fazendo referências explícitas a ela tanto em sua arte quanto em seus escritos" (DUCHTING, 2020, p. 7). Grandes compositores, como Igor Stravinsky (1882-1971) e sua música serialista, estavam concatenados com o universo visual de cenários e balés. Heitor Villa-Lobos (1887-1959) usou em suas obras Melodia das montanhas e Skyline melody um processo que chamou de milimetria, em que transformava o contorno de imagens da paisagem em composições musicais. Claude Debussy (1862-1918) era um apaixonado pelas artes visuais. Possuía um apreço tão forte pelos pintores que invariavelmente tinha suas composições relacionadas, mesmo que metaforicamente, a obras de artistas que ele admirava, como Degas, Renoir, Gauguin e Manet, ou a arte japonesa de HoKusai. Retornando ainda mais no tempo, no período romântico, deparamo-nos com G. E. Lessing (1729-1781), filósofo e crítico de arte, comparando o efeito semelhante que a poesia e a pintura causavam no receptor. (LESSING, 1766, 
p. 77). Continuando nesse retorno, encontraremos o paragone ${ }^{1}$ renascentista: a disputa comparativa sobre as obras acabadas da escultura e da pintura e que pode ter introduzido o entendimento sobre a fonte única da qual emanam todas as artes. Essa fonte seria o próprio ser humano no seu mais recôndito interior, em seu sentimento existencial. Por certo, sabemos que essa interação é tão antiga quanto o fazer artístico. As interatividades artísticas entre linguagens, seja pintura, escultura, música, arquitetura, dança, escultura ou teatro, fazem parte do corpus de todo objeto artístico.

Operando nas fronteiras de cada linguagem, o conceito de interartes evoca discussões intensas sobre os limites e as possibilidades reais ou abstratas desse fenômeno. As críticas sobre a inserção de uma linguagem em outra, defendida por artistas e pesquisadores como Wassily Kandinsky, possuem opositores que discordam desses pressupostos, afirmando que tal mistura não traz nenhum benefício ao objeto artístico. Clement Greemberg (1909-1994) entendia que a especificidade de cada linguagem era definitiva e possuía fronteiras erguidas por suas materialidades, cada qual com o seu próprio caminho e seu espaço exclusivo, por onde alcança grandeza, arte pura, livre de influências e livre dentro de suas regras específicas (FERREIRA; COTRIM, 1997, p. 101).

Tais discussões, ainda hoje, estão presentes em debates dentro dos institutos de Arte. Nesses institutos, o formato de cada curso de graduação propõe a formação específica de uma linguagem artística, como teatro, artes visuais, dança ou música. Esse formato hermético pode pôr obstáculos nas possibilidades de comunicação entre as linguagens artísticas diversas, dificultando também os diálogos com disciplinas não específicas da arte.

Vejamos, como exemplo, as grades curriculares do Instituto de Artes da Universidade Federal de Uberlândia (MG) (larte-UFU) e as disciplinas ofertadas no 1o período de cada curso do larte-UFU no Quadro 1.

\begin{tabular}{|c|c|c|c|}
\hline Artes visuais & Música & Teatro & Dança \\
\hline $\begin{array}{l}\text { Educação em artes } \\
\text { visuais }\end{array}$ & Teoria da música & Corpo e voz & Corpo e voz \\
\hline $\begin{array}{l}\text { Risco, gesto e } \\
\text { marca }\end{array}$ & Percepção musicali & $\begin{array}{l}\text { Transformaçōes das } \\
\text { tradiçōes teatrais } \\
\text { clássicas }\end{array}$ & $\begin{array}{l}\text { Introdução à educação } \\
\text { somática }\end{array}$ \\
\hline Corpo, arte e vida & $\begin{array}{l}\text { Música, história e } \\
\text { cultura }\end{array}$ & Recepçāo cênica 1 & $\begin{array}{l}\text { Introduçāo aos conceitos de } \\
\text { cultura e memória }\end{array}$ \\
\hline Cor e composição & Prática musical & Atuação: improvisação & $\begin{array}{l}\text { Dança contemporânea: } \\
\text { técnica e composiçāo }\end{array}$ \\
\hline \multirow{3}{*}{$\begin{array}{l}\text { História da arte: } \\
\text { modernae } \\
\text { contemporânea }\end{array}$} & Canto coral 1 & & Corpo, ritmo e musicalidade \\
\hline & $\begin{array}{l}\text { Música e tecnologia } \\
\text { na produção musical }\end{array}$ & & $\begin{array}{l}\text { Atividades acadêmicas } \\
\text { complementares }\end{array}$ \\
\hline & $\begin{array}{l}\text { Formação do } \\
\text { profissional da } \\
\text { música }\end{array}$ & & \\
\hline
\end{tabular}

Quadro 1 - Descritivo da grade curricular com disciplinas obrigatórias do 1ำ período. Fonte: larte-UFU (2021).

\footnotetext{
${ }^{1}$ Renaissance paragone: pintura e escultura. Em um contexto da história da arte, a palavra italiana paragone ("comparação", pl. paragoni) pode se referir a qualquer uma das várias discussões teóricas que informaram o desenvolvimento da teoria artística na Itália do século XVI. Isso inclui a comparação entre as diferentes qualidades estéticas das escolas centrais de pintura italiana e veneziana (o chamado disegno / colore paragone) e se a pintura ou a literatura era o meio mais convincente e descritivo. Mas o termo paragone geralmente se refere ao debate sobre os méritos relativos da pintura e escultura durante o período renascentista (https://www.oxfordartonline.com/page/renaissance-paragone-painting-andsculpture).
} 
Podemos observar nesse quadro a distinção que cada curso apresenta na oferta de suas respectivas disciplinas ${ }^{2}$. É importante salientar que esse recorte nos diz apenas sobre a introdução de cada curso, seu início; porém, pelos estudos das grades curriculares propostas, observa-se um trajeto autônomo e com mínimas interações disciplinares entre os cursos do instituto. Vale ressaltar que a disciplina Corpo e voz, oferecida tanto pelo curso de Teatro quanto pelo curso de Dança, possui em suas fichas curriculares informações que mostram o caráter formativo da disciplina, como estudos de técnica vocal e corporal e de reconhecimento de possibilidades individuais de atuação. Isso difere da nossa busca, que é a interação entre as artes dentro do processo criativo de produção artística do estudante. Em uma leitura por toda a grade curricular desses cursos, não foi observada nenhuma correspondência curricular que pudesse propor uma intenção de estudo e pesquisa sobre as interartes.

No currículo de 2007 do curso de Artes Visuais, descontinuado em 2019, encontramos a disciplina Interfaces da arte. Essa disciplina trazia em sua ementa o seguinte texto: "Estudo das artes visuais em aproximação com as várias áreas do conhecimento, enfatizando suas relações na história e na contemporaneidade com a filosofia, as ciências sociais, a tecnologia e a interação das artes"3. A disciplina Interfaces da arte deixou de ser obrigatória e passou a ser opcional no currículo de 2019, sendo a única a fazer uma aproximação entre as artes nas propostas das grades curriculares dos cursos de graduação do larte-UFU.

Qual seria, então, a realidade em outros cursos de graduação em Arte no Brasil em relação às interartes? Numa pesquisa em outras matrizes curriculares, buscamos disciplinas cujos nomes continham termos como interfaces, multimeios e/ou intermídias. Vejamos alguns exemplos no Quadro 2.

\begin{tabular}{|c|c|c|}
\hline Universidade & Curso & Disciplina e ementa \\
\hline $\begin{array}{l}\text { Universidade Estadual de } \\
\text { Santa Catarina (Udesc) }\end{array}$ & Artes visualis & 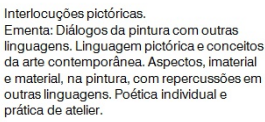 \\
\hline $\begin{array}{l}\text { Universidade Estadual de } \\
\text { Santa Catarina (Udesc) }\end{array}$ & Artes visuais & 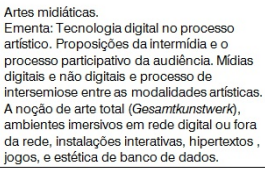 \\
\hline $\begin{array}{l}\text { Universidade do Estado do } \\
\text { Rio de Janeiro (UER.J) }\end{array}$ & Desenho industrial & 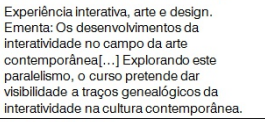 \\
\hline $\begin{array}{l}\text { Universidade do Estado do } \\
\text { Rio de Janeiro (UERJ) }\end{array}$ & Artes visuais & $\begin{array}{l}\text { Pinturae intermeios. } \\
\text { Ementa: Aprofundamento das questôes } \\
\text { fundamentais da Pintura na Arte } \\
\text { Contemporânea. Aproximar rnomenclaturas } \\
\text { como deserho, pintura, estruturas } \\
\text { bidimensionais, imagem técnica e } \\
\text { midilátical[...]. }\end{array}$ \\
\hline
\end{tabular}

Quadro 2 - Disciplinas ofertadas em cursos de graduação em Arte no Brasil. Fonte: Elaborado pelo autor (2021).

\footnotetext{
$\overline{2}$ Na disciplina Prointer (Projeto interdisciplinar), disponível para todos os cursos do larte-UFU, apesar de o nome sugerir uma possível leitura de interartes, não foi observada em suas fichas curriculares nenhuma relação com o tema das correspondências das artes.

${ }^{3}$ www.iarte.ufu.br/sites/iarte.ufu.br/files/media/publicacoes/topicos_especiais_em_interfaces_da_arte__iarte39041.pdf
} 
Não se pode afirmar que as interartes não estejam presentes nos currículos disciplinares das graduações, mas o aprofundamento e a importância talvez estejam distantes da forma como a arte, principalmente a arte contemporânea, tem dialogado com todas as linguagens. Observa-se que o estudo das interações das artes está incluso no processo de ensino-aprendizado e no processo de pesquisa nos cursos de graduação (bacharelado) em Arte nas universidades públicas pesquisadas. É importante frisar que essas observações referem-se a cursos de bacharelado e que, para os egressos dos cursos de licenciatura em Arte, seja qual for a linguagem artística escolhida, o trabalho de docência terá por obrigação imposta pela Base Nacional Comum Curricular (BNCC) ${ }^{4}$ uma articulação de ensino das linguagens artísticas: artes visuais, música, teatro e dança.

Nos cursos de pós-graduação, o processo de inserção das disciplinas que tratam das interartes, até pela premissa investigativa dos mestrados, aparece de forma substancial no campo da pesquisa em Arte e, por conseguinte, com menor enfoque na questão formativa. Cito alguns desses cursos e suas disciplinas de correspondências em artes no Quadro 3.

\begin{tabular}{|l|l|l|}
\hline \multicolumn{1}{|c|}{ Universidade } & \multicolumn{1}{|c|}{ Curso } & \multicolumn{1}{c|}{ Disciplina } \\
\hline $\begin{array}{l}\text { Universidade } \\
\text { Federal da Bahia } \\
\text { (UFBA) }\end{array}$ & $\begin{array}{l}\text { Escola de Belas Artes, Programa } \\
\text { de Pós-graduação em Artes } \\
\text { Visuais }\end{array}$ & $\begin{array}{l}\text { Pintura: linguagem e interfaces. } \\
\text { Ementa: Componentes estruturais da linguagem } \\
\text { pictórica. As construções da visualidade } \\
\text { pictórica: os significantes e os modos de ver. } \\
\text { Interface da pintura com outras linguagens. }\end{array}$ \\
\hline $\begin{array}{l}\text { Universidade } \\
\text { Federal do Pará } \\
\text { (UFPA) }\end{array}$ & $\begin{array}{l}\text { Instituto de Ciências da Arte, } \\
\text { Programa de Pós-graduação em } \\
\text { Artes }\end{array}$ & $\begin{array}{l}\text { Produção estética das linguagens artísticas. } \\
\text { Ementa: Estudos sobre a produção poética da } \\
\text { linguagem e sua função na constituição da } \\
\text { memória cultural. Gestualidade, sonoridade, } \\
\text { verbalidade e visualidade: semioses e } \\
\text { abordagens interativas da linguagem em } \\
\text { produções artístico-estéticas. }\end{array}$ \\
\hline $\begin{array}{l}\text { Universidade de } \\
\text { Campinas } \\
\text { (Unicamp) }\end{array}$ & $\begin{array}{l}\text { Instituto de Artes, Departamento } \\
\text { de Música }\end{array}$ & $\begin{array}{l}\text { Seminários avançados. } \\
\text { Ementa: Compreender o papel de relevo da } \\
\text { interdisciplinaridade do conhecimento nas } \\
\text { análises e interpretações culturais em torno da } \\
\text { linguagem musical, como ocorre nas relações } \\
\text { da história com a semiótica, linguística, } \\
\text { comunicação, sociologia, (etno) musicologia, } \\
\text { antropologia, política, economia, língua e } \\
\text { literatura. }\end{array}$ \\
\hline
\end{tabular}

Quadro 3 - Disciplinas ofertadas em cursos de pós-graduação em Arte no Brasil. Fonte: Elaborado pelo autor (2021).

O interesse das interartes nos cursos de pós-graduação vai além das linhas de pesquisa dos cursos das áreas de Arte. As investigações servem tanto para a produção artística - oferecendo subsídios para experimentação - como para a compreensão dos processos criativos interartísticos e das discussões em campos diversos. Ainda na pesquisa de pós-graduação, muito tem se falado sobre a questão artística em termos de multimeios e multimídias. Essas definições

\footnotetext{
$\overline{{ }^{4} \mathrm{Na} \mathrm{BNCC}}$, no Ensino Fundamental, o componente curricular Arte está centrado nas seguintes linguagens: as artes visuais, a dança, a música e o teatro. Essas linguagens articulam saberes referentes a produtos e fenômenos artísticos e envolvem as práticas de criar, ler, produzir, construir, exteriorizar e refletir sobre formas artísticas. A sensibilidade, a intuição, o pensamento, as emoções e as subjetividades se manifestam como formas de expressão no processo de aprendizagem em arte.
} 
semânticas acrescentam à produção do objeto de arte conceitos, técnicas e materialidades tecnológicas digitais, como mídias digitais e virtuais, que trazem novos objetos artísticos - audiovisualidades digitais, interatividade obra-espectador, paisagens e esculturas sonoras. As intermídias são diálogos entre as artes agora com experimentos tecnológicos. Trata-se de um conceito de interartes digitais, que difere das interartes tradicionais no sentido de materialidades, analógicas opostas ao meio digital, porém formuladas na inter-relação das linguagens: música, poesia, artes visuais, dança e teatro.

\section{A produção de pesquisa científica atual no campo das interartes entre a música e a pintura}

As pesquisas sobre as artes e suas correspondências desdobram-se em vários campos de relação interartística, como dança e pintura; música e cena; poesia e música; filosofia e teatro, e outras várias combinações. Ainda é possível combinar três ou mais linguagens artísticas, que estão postas e são possíveis de serem investigadas. É considerada de grande importância a investigação interartística, em qualquer época ou movimento, que se fez presente no dia a dia de artistas, pesquisadores, estudiosos de arte, filósofos e pensadores. E o que se pesquisa hoje nas academias dentro do universo das relações entre as artes é o que apresento a partir de uma busca de registros dos repositórios de instituições e agências ligadas ao sistema de educação e de pesquisa do país. Nessa busca, os dados obtidos mostram como as interartes têm despertado interesse nos mais diversos campos de pesquisa acadêmica (Quadro 4).

\begin{tabular}{|l|l|l|l|c|}
\hline \multicolumn{1}{|c|}{ Banco de dados } & \multicolumn{1}{|c|}{ BDTD } & \multicolumn{1}{c|}{ Capes } & \multicolumn{1}{c|}{ Google Acadêmico } & Total \\
\hline Música e pintura & $\begin{array}{l}10 \text { dissertações, } \\
7 \text { teses }\end{array}$ & 7 artigos & 571 artigos & 595 \\
\hline Estética comparada & $\begin{array}{l}6 \text { teses, } \\
5 \text { dissertações }\end{array}$ & 6 artigos & 6 artigos & 23 \\
\hline $\begin{array}{l}\text { Sonoridades e } \\
\text { visualidades }\end{array}$ & $\begin{array}{l}26 \text { dissertações, } \\
8 \text { teses }\end{array}$ & 1 artigo & 34 artigos & 69 \\
\hline $\begin{array}{l}\text { Correspondência das } \\
\text { artes }\end{array}$ & 1 dissertação & 3 artigos & $\begin{array}{l}128 \text { artigos contendo as } \\
\text { palavras "música e pintura" }\end{array}$ & 132 \\
\hline Interartes & $\begin{array}{l}36 \text { dissertações, } \\
21 \text { teses }\end{array}$ & $\begin{array}{l}43 \text { artigos, } \\
2 \text { livros, } \\
1 \text { resenha }\end{array}$ & $\begin{array}{l}16 \text { artigos contendo as } \\
\text { palavras "música e pintura" }\end{array}$ & 119 \\
\hline Interfaces da arte & $\begin{array}{l}7 \text { dissertações, } \\
6 \text { teses }\end{array}$ & 1 artigo & $\begin{array}{l}115 \text { artigos contendo as } \\
\text { palavras "música e pintura" }\end{array}$ & 129 \\
\hline \multicolumn{5}{|r|}{} \\
\hline
\end{tabular}

Quadro 4 - Dados absolutos da pesquisa sem cruzamento de delineadores. BDTD Biblioteca Digital Brasileira de Teses e Dissertações, Capes - Coordenação de Aperfeiçoamento de Pessoal de Nível Superior. Fonte: Elaborado pelo autor (2020).

$\overline{{ }^{5} \text { Notas de }}$ diário durante a residência artística "abrindo a sala". 
Optei também por realizar apurações que delimitassem uma relação interartística específica, por exemplo, o binomial das interartes música/pintura, o que trouxe um resultado bastante expressivo. No Quadro 5, apresento o resultado com delineadores que buscam exatamente essa especificidade relacional entre a música e a pintura.

\begin{tabular}{|c|c|c|c|c|}
\hline Banco de dados & BDTD & Capes & $\begin{array}{c}\text { Google } \\
\text { Acadêmico }\end{array}$ & Total \\
\hline Música/pintura e estética comparada & $\begin{array}{l}6 \text { documentos } \\
\text { (2 dissertações, } \\
4 \text { teses) }\end{array}$ & 7 artigos & 28 artigos & 42 \\
\hline $\begin{array}{l}\text { Sonoridades e visualidades e } \\
\text { estética comparada }\end{array}$ & $\begin{array}{l}7 \text { documentos } \\
\text { (3 dissertações, } \\
4 \text { teses) }\end{array}$ & 0 & 1 artigos & 8 \\
\hline $\begin{array}{l}\text { "Correspondência das artes" e } \\
\text { "música e pintura" }\end{array}$ & 0 documentos & 0 & 11 artigos & 11 \\
\hline "Interartes" e "música e pintura" & $\begin{array}{l}5 \text { documentos } \\
\text { (4 dissertações, } \\
1 \text { tese) }\end{array}$ & $\begin{array}{l}46 \text { documentos } \\
\text { ( } 43 \text { artigos, } \\
3 \text { livros,) }\end{array}$ & 21 artigos & 73 \\
\hline \multirow[t]{2}{*}{ Interfaces da arte e música e pintura } & $\begin{array}{l}1 \text { documento } \\
\text { (1 dissertação) }\end{array}$ & 3 artigos & 0 artigos & 4 \\
\hline & & & TOTAL & 138 \\
\hline
\end{tabular}

Quadro 5 - Dados obtidos após aplicação dos novos critérios de cruzamento, com o binomial música/pintura. Fonte: Elaborado pelo autor (2020).

Excluindo desdobramentos e estudos que não possuem proximidade com a correspondência entre música e pintura, destaco alguns trabalhos referenciais para o processo interartístico da música e da pintura. Dentre esses trabalhos, chama a atenção o de Jean-Yves Bosseur, Musique et arts plastiques: interactions aux XXe et XXIe siècles Troisième édition revue et augmentée (2015). Trata-se de um estudo de excelência e de grande relevância teórica e produtiva, com análises de correspondências sensoriais e equivalências estruturais entre a música e as artes visuais. É sobre o trabalho de Bosseur que Alexandre Siqueira Freitas insere suas pesquisas na área das semelhanças entre música e arte visual. Sua tese Ressonâncias, reflexos e confluências: três maneiras de conceber as semelhanças entre o sonoro e o visual em obras do século XX (FREITAS, 2012) é um primoroso trabalho que investiga as sínteses dessas artes.

O trabalho de Sandra Loureiro de Freitas Reis (1999), A linguagem oculta da arte impressionista: tradução intersemiótica e percepção criadora na literatura, música e pintura, traz conceitos comuns às linguagens artísticas da música e da pintura. A partir desses conceitos, a autora elabora as correspondências que estariam ocultas ou que foram ocultadas pelas especificidades de cada linguagem.

No âmbito da apreciação analítica de uma obra pictórica, musical e literária, de qualquer época ou estilo, podemos considerar, na análise 
do fenômeno poético em seu sentido amplo (poiesis), os seguintes modos, aqui vistos como organizações peculiares de elementos da mesma espécie, num determinado sentido lógico: modos de valores; modos de durações ou modos rítmicos; modos de intensidade; subdivididos estes em: modos de agógica, de dinâmica e de densidades; modos de planos, modos de timbres, cores e tons; modos de discurso; modos de justaposição e de simultaneidades; modos de articulação; modos de luz; modos de estrutura; modos de instrumentação; modos de direcionalidades; modos de significação; modos de leitura e modos de interpretação (REIS, 2001, p. 382).

Outros trabalhos seguem a mesma linha investigativa e apresentam teses que transitam pela sinestesia e pela intermidialidade. São eles:

BAQUERIZO, Daniel Mancero. Le marché populaire: trois tableaux sonores: aisthêsis, création et correspondance entre musique et peinture.

HAMIDO, Omar Costa. Estudo sobre as relações entre Música e Pintura e processos composicionais.

LOUREIRO, Eduardo Campolina Viana. A técnica e os processos criativos no século $X X$ : entre as artes visuais e a música. introdução.

JUNIOR PEDROSO, Neurivaldo Campos. Estudos Interartes: uma

VILLASE, Humberto Ortega. Desafios del potencial creativo de la intermedialidad.

Esse conjunto de estudos anotados compõe um generoso corpus de trabalhos sobre as correspondências das artes e os processos criativos de interfaces. São trabalhos atuais que dialogam com teses como a de Etienne Souriau (1947) e seus sistemas de correspondências das artes, caminhos para estudos interartísticos da música com a literatura ou da música com as artes visuais. Souriau (1947) busca legitimar os métodos comparativos a partir do confronto entre as artes e comenta que todos que se empenham nessa aventura comparativa

\footnotetext{
Participam mais intimamente e achando encantos maiores aqueles que saboreiam as profundas delícias de avançar pelo fato (e esse fato é a própria arte, com todas as suas graças, mas também com toda a sua robustez e profundidade) passo a passo, como o auxílio de um método rígido e exigente, que engrandece o estético como todas as suntuosidades do espírito puro, todos os sombrios clarões desse pensamento precavido e pesquisador, pensamento que não teme avançar ao âmago das coisas virando e revirando o fato até que ele diga seu verdadeiro nome (SOURIAU, 1947, p. 27).
} 
Nesse avançar dentro das artes e suas linguagens singulares, a pesquisa de estética comparada de Souriau se aprofunda para encontrar interseções artísticas. Etienne Souriau (1947) fala das correspondências no objeto artístico acabado. No entanto, poderiam a interação entre as artes acontecer durante o processo criativo, como nas relações das linguagens nos processos criativos na abordagem dos estudos de Fayga Ostrower (2014), no livro Criatividade e processos de criação. Nele, ela apresenta formulações criativas a partir da tradução e da transposição, elementos que no processo criativo são ferramentas do artista na concepção e produção de sua obra. Na transposição, aproximamo-nos mais do processo criativo das interartes. Transpor um elemento para outro é, numa hipótese provável, comparar signos, ressignificar elementos, utilizar estéticas distintas para unir diferentes linguagens. $\mathrm{Na}$ tradução, encontramos o objeto artístico pronto. Entendemos, então, que são dois caminhos para o estudo das interartes: um que olha para a correspondências das artes no processo criativo e outro que olha para as correspondências a partir do objeto artístico acabado.

Na proposta de trabalho do pesquisador e artista francês Jean-Yves Bosseur sobre a música e as artes plásticas, o processo interartístico é posto sobre o fazer artístico. Artes plásticas e música se intercalam, e o objeto artístico resultante desse enlace surge atemporal e inédito.

Se as intersecções entre música e artes plásticas não cessaram de se desenvolver ao longo de todo o nosso século, segundo modalidades tão diversas como as estéticas a que se referem, as problemáticas que as sustentam parecem já expressas sob múltiplas formas nos séculos anteriores. Em seu Dicionário de música, em o artigo "Imitação", Jean-Jacques Rousseau escreve: "A música parece colocar o olho no ouvido; e a grande maravilha de uma arte que age apenas pelo movimento é poder formar até a imagem do descanso. A noite, o sono, a solidão e o silêncio entram nos quadros grandes da música". (BOSSEUR, 2015, p. 10) ${ }^{5}$

A partir dos estudos de Jean-Yves Bosseur (2015), o pesquisador e professor Alexandre Siqueira Freitas (2012), autor da tese Ressonâncias, reflexos e confluências: três maneiras de conceber as semelhanças entre o sonoro e o visual em obras do século XX, debruça-se nas pesquisas sobre as interartes, apresentando "diretrizes para se observar encontros entre artes, matérias e técnicas artísticas distintas e caracterizar algumas das passagens possíveis e interações entre o sonoro e o visual" (FREITAS, 2012, p. 25). Ele afirma que

As semelhanças são expostas, mais à frente, através de traços específicos, aos quais chamamos de "similitudes", de acordo com o

\footnotetext{
5 Texto original em francês: Si les intersections entre musique et arts plastiques n'ont cessé de se développer tout au long de notre siècle, selon des modalités aussi diversifiées que les esthétiques auxquelles elles renvoient, les problématiques qui les sous-tendent semblent déjà exprimées sous de multiples formes au cours des siècles précédents. Dans son Dictionnaire de musique, à l'article «Imitation », Jean-Jacques Rousseau écrit: "La musique semble mettre l'œil dans l'oreille; et la plus grande merveille d'un art qui n'agit que par le mouvement est de pouvoir former jusqu'à l'image du repos. La nuit, le sommeil, la solitude et le silence entrent dans le nombre des grands tableaux de la musique".
} 
entendimento de Michel Foucault. A partir dessas últimas, apresentadas pelos nomes de simpatia, emulação, analogia e convenientia, propomos maneiras de se observar encontros entre o sonoro e o visual. Da simpatia provém a noção ressonância, que se baseia na liberdade do receptor de estabelecer correspondências entre pares de obras de arte distintas e fertilizar mutuamente seus entendimentos. Os reflexos se endereçam às obras cujos artistas procuraram aplicar em sua própria arte elementos provindos de uma outra arte e encontram suas bases nas similitudes de emulação e analogia. Finalmente, as confluências. Neste terceiro grupo incluem-se obras que contém em sua própria estrutura matérias sonoras e visuais. (FREITAS, 2012, p. 11)

Para Freitas (2012), o desafio da estética comparada traz apontamentos fundamentais para o campo das comparações e correspondências das artes: "Não temos dúvidas de que existam diferenças entre as naturezas perceptivas de cada arte, mesmo que os limites entre atividades artísticas nem sempre sejam claros. A classificação das práticas artísticas pode constituir um primeiro problema no exercício da estética comparada" (FREITAS, 2008, p. 2). São diálogos e atravessamentos entre as artes que formulam várias hipóteses e possibilidades de estudos sobre o tema das correspondências - onde e como as interartes se manifestam ou se revelam.

\section{Interartes: um histórico dos estudos das correspondências artísticas}

Estudos sobre as interartes são abordados desde a filosofia grega. $\mathrm{Na}$ Grécia, mediadas pela música, diversas linguagens artísticas cumpriam o papel de proporcionar conhecimentos e sabedoria. Para o professor Fernando Santoro 6 (2012), essas atividades seriam as seguintes:

Os gregos chamam de músicas as atividades artísticas: a epopeia, a tragédia, a comédia, a poesia lírica, a erótica. Também chamam de música atividades que como tal nos soam inusitadas, como a astronomia e a história [...] Aristóteles chama as músicas didáticas de "éticas", pois o que se aprende com seus mitos é o éthos heroico, os valores que dignificam uma pessoa [...] A arte também é catártica, transformando as emoções humanas como o terror, a compaixão e a cólera. Aristóteles percebe que a provocação e transformação das emoções humanas nas obras poéticas é tanto ou mais importante que a expressão de conteúdos morais. (SANTORO, 2012) ${ }^{7}$

Já durante o período renascentista, são as artes visuais que reivindicam o protagonismo, confrontando a poesia numa disputa conhecida como paragone. G. E. Lessing (2020) trata desse enlace em seu livro Laocoonte, no qual descreve que,

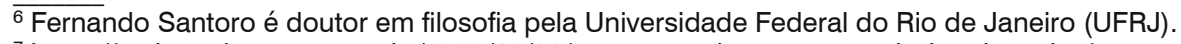

${ }^{7}$ https://revistaeducacao.com.br/2012/12/03/a-arte-na-educacao-a-partir-de-aristoteles/ 
apesar da relação conflituosa entre poesia e pintura, "ambas eram tão exatamente ligadas que sempre caminhavam de mãos dadas e o poeta nunca perdia o pintor de vista e o pintor o poeta" (LESSING, 2020, p. 77). Mas onde está materialmente a interação entre as artes? A interação pode estar e pode acontecer antes da concretização material do objeto artístico (HAMIDO, 2013, p. 21). Então, seria não somente no conhecimento artístico específico de cada artista, mas na possibilidade que cada artista se dispõe e se abre para receber influências de objetos artísticos diversos do seu que, partindo desse ponto, tais influências se inserem no seu processo de criação como materialidades objetivas ou subjetivas de outras linguagens. Dessa forma, cria-se um campo de correspondências interartes.

Tratando as interartes com outro olhar, mas com o mesmo vigor, são os românticos e pós-românticos os mais enfáticos nas correspondências entre as artes. Músicos como Tchaikovsky, Debussy, Arnold Schonberg e pintores impressionistas e modernos estão sempre abordando as interações entre as artes, especialmente entre a pintura e a música. Em contrapartida, é nesse momento que surge um dilema: a superficialidade das comparações. Essa questão é abordada por Souriau (1947, p. 3), que trata esse dilema como "metáforas imprecisas e analogias confusas". Tais analogias aparecem no período romântico e impressionista e só irão desaparecer no início do século $\mathrm{XX}$ pelo rigor das pesquisas em tradução e literatura comparada, nos estudos de semiótica e sobre estética comparada.

A ciência exata também buscou uma relação entre as naturezas de cada arte em suas materialidades. Essa procura aparece no livro $A$ teoria das cores, do alemão Johann Wolfgang von Goethe (1749-1832), publicado em 1810, e nas teorias de Isaac Newton (1642-1726) sobre a relação das frequências de sons e cores. Esses são dois exemplos de pesquisas que exploraram o aprofundamento sobre o comum que permeia as linguagens artísticas e suas especificidades.

Podemos argumentar que a materialidade do objeto artístico precede a comunhão entre as artes, ou seja, as interartes, a correspondência e a interação acontecem durante o processo criativo, na inspiração e no desejo de expressão. É preciso pensar como acessar e conceituar esses insights, seja pela fenomenologia ${ }^{8}$ ou pelas correspondências, pelas analogias e semelhanças, pela crítica genética, ou pela semiótica. São muitos os caminhos, e todos são possíveis de serem trilhados.

\section{CONCLUSÃO}

A arte é um universo expansivo, e suas possibilidades relacionais podem levar a grandezas inimagináveis, como na relação entre música e pintura, teatro e pintura, música e dança, literatura e música, performances e pintura, enfim, um universo de fenômenos desafiadores, de encontros e desencontros de processos criativos de linguagens tão distintas. Para o pesquisador Alexandre Freitas, "A realidade da diferença das coisas não impede que semelhanças, objetivas ou não, e

\footnotetext{
${ }^{8} \mathrm{~A}$ fenomenologia surge na filosofia como ciência sobre a experiência que a consciência tem do mundo, a relação entre a consciência do saber humano e o mundo exterior a ela. Portanto, seu principal objetivo é investigar e descrever os fenômenos como experiência consciente. Isso deve se dar de forma desvinculada de teorias sobre as explicações causais e o mais distante possível de preconceitos e pressuposições, como afirmou Merleau-Ponty, no prefácio da Fenomenologia da percepção (https://namu.com.br/portal/o-que-e/fenomenologia/).
} 
de todas as naturezas, possam ser observadas"(FREITAS, 2012, p. 86). Para Fayga Ostrower, "O que for semelhante física, intelectualmente, emocionalmente semelhante, tende a atrair-se.[...] $O$ que for dessemelhante tende a destacar-se. Destacando-se, o contraste se segrega no contexto". (OSTROWER, 2016, p. 92). Esses semelhantes de processos criativos e de objeto artístico parecem ondas paralelas que se cruzam intensa e intencionalmente; são os caminhos paralelos que se cruzam por ressonâncias, por objetivos, por analogias, por inspiração. Compreendo que o produto entregue por uma pesquisa científica em Arte possa trazer mais questionamentos e discussões sobre os processos artísticos, sobre os métodos do fazer artístico. As teorias da sistematização, necessárias às pesquisas científicas, esbarram no caráter por vezes intuitivo da arte, que tencionam para um modo diferente de pesquisa. Para Sílvio Zamboni (2012, p. 44),

O caminho da adequação em arte não é necessariamente o mais curto e mais imediato para se atingir um objetivo, porque o processo de trabalho, principalmente na pesquisa artística, é permeado por inúmeros fatores não racionais e não controlados pelo intelecto do artista e, portanto, pode necessitar de caminhos menos diretos para que se dê a maturação necessária das soluções objetivadas pelo artista.

Temos, portanto, um breve panorama sobre a participação da disciplina de interartes no contexto do ensino nos institutos de Arte das universidades brasileiras. Este panorama revela um olhar para o campo de pesquisa em interartes e as correspondências das artes, o qual, por transitar em diversas áreas, cada qual com suas particularidades, provoca um certo receio e uma prudência dos pesquisadores para falar em uma língua da qual não possuem total domínio. Tal domínio certamente é necessário - para traduzir uma língua para outra, de uma área de pesquisa para outra - para evitar as temíveis e inoportunas metáforas para as quais Souriau (1947) alertava. Atentos a essas dificuldades, pesquisadores buscam o entendimento e a compreensão, seja na produção da arte com o uso de interfaces da arte na concepção de objetos artísticos, seja na percepção de processos criativos alheios, percebendo ramificações dessas dialéticas artísticas em áreas que vão desde a didática em artes até as significâncias inéditas reivindicadas pela semiótica. Creio que será nos processos criativos que encontraremos uma possibilidade maior de confirmarmos, de maneira científica, os processos interartísticos. Tais confirmações devem ser livres de analogias abstratas e devem trazer embasamentos sólidos. Esses trabalhos por certo auxiliarão outras pesquisas, tornando possível o aprofundamento nas estéticas comparadas.

Também é importante não deixar de pensar na arte-educação, no ensino de arte na educação básica. Institutos de Arte têm formado docentes que, para atuarem na sala de aula, necessitarão de um conhecimento, mesmo que básico, nas quatro linguagens exigidas pelas bases curriculares. Esses professores vão transitar no teatro, na dança, na música e nas artes visuais. Podem abordar separadamente cada linguagem, mas, de posse do conhecimento sobre a interação dessas linguagens, é certo que a qualidade de seu trabalho será superior. 
As análises dessas pesquisas podem trazer discussões sobre o ambiente educacional da arte no ensino fundamental e no ensino superior, separando contextos e objetivos de cada nível. Indubitavelmente, será uma grande contribuição das artes para o crescimento de todos os campos científicos dispostos ao diálogo e ao (con)viver e ao (co)existir com a arte; uma porta para entrada de novos estudos científicos e sua samsara ${ }^{9}$ e para a arte em suas aventuras.

\section{REFERÊNCIAS}

BOSSEUR, Jean-Yves. Musique et arts plastiques: interactions aux XXe et XXle. Paris: Minerve, 2015.

FERREIRA, G.; COTRIM, C. (org.). Clement Greenberg e o Debate Crítico. Rio de Janeiro: Funarte; Jorge Zahar, 1997.

DUCHTING, Haio, Paul Klee: Painting Music. London: Prestel, 2020.

FREITAS, Alexandre S. Ressonâncias, reflexos e confluências: três maneiras de conceber as semelhanças entre o sonoro e o visual em obras do século XX. 2012. Tese (Doutorado) - Universidade de São Paulo, São Paulo, 2012.

FREITAS, Alexandre. Desafios da estética comparada. In: CONGRESSO DA ASSOCIAC A O NACIONAL DE PESQUISA E PO S-GRADUAC A O (ANPPOM), 2008, [s. I.]. [Anais]. [S. I.], 2008.

LESSING. G. E. Laocoonte: ou sobre as fronteiras da pintura e da poesia. São Paulo: lluminuras, 2020.

MOREIRA, Walter. Revisão de literatura e desenvolvimento científico: conceitos e estratégias para confecção. Janus, Lorena, SP, v. 1, n. 1, 2004.

OSTROWER, Fayga. Criatividade e processos de criação. 30. ed. rev. Petrópolis: Vozes, 2014.

PIZZANI, Luciana; SILVA, Rosimary C.; BELLO, Suzilei F.; INNOCENTINI, Maria C. A arte da pesquisa bibliográfica na busca do conhecimento. Revista Digital de Biblioteconomia e Ciência da Informação, Campinas, v. 10, n. 2, out. 2012.

REIS, Sandra L. F. A linguagem oculta da arte impressionista, música e pintura. Belo Horizonte: Mãos Unidas, 2001. $447 \mathrm{p}$.

SOURIAU, Étienne. A correspondência das artes: elementos de estética comparada. São Paulo: Cultrix, 1969.

ZAMBONI, Silvio. Pesquisa em arte: um paralelo entre arte e ciência. 4. ed. rev. Campinas: Autores associados, 2012.

\footnotetext{
8 Samsara, o termo sânscrito e páli para "movimento contínuo" ou "fluxo contínuo", refere-se, no budismo, ao conceito de nascimento, velhice, decrepitude e morte, do qual todos os seres no universo participam e do qual só se pode escapar por meio da iluminação.
} 
Recebido em 15/05/2021 - Aprovado em 21/09/2021

Como citar:

RAMOS, E. As interartes e seu lugar no contexto atual disciplinar dos cursos de graduação e pós-graduação em arte nas universidades brasileiras. ouvirOUver, v.17, n.2. p. 269-283. jul./dez. 2021. https://doi.org/10.14393/OUV-v17n2a2021-61093

(c) (7) (8) A revista ouvirOUver está licenciada com uma Licença Creative Commons Atribuição-NãoComercial 4.0 Internacional. 